\title{
TATA KELOLA PERENCANAAN SISTEM TEKNOLOGI INFORMASI DAN KOMUNIKASI (TIK)
}

\author{
Bahrawi \\ Balai Pengkajian dan Pengembangan Komunikasi dan Informatika (BPPKI) Manado. Jalan Pumorow No. 76 \\ Manado, telp 0431-858268. Hp.085336861945.E-mail: bahrawi@kominfo.go.id; awianggara@gmail.com \\ Naskah diterima tanggal 13 Februari 2015, direvisi tanggal 21 Mei 2015, disetujui tanggal 22 Juni 2015.
}

\section{GOVERNANCE OF INFORMATION AND COMMUNICATION TECHNOLOGY (ICT) SYSTEM PLANNING}

\begin{abstract}
The intensity of ICT usage continues to increase. This should be accompanied by the increase of the government's performance, and one of the important components is governance of the ICT system planning. The ICT system planning with a good management will provide significant benefits to the organization. One cause of insignificant benefits ICT to the organizational goals is there is no ICT governance applied. It can be caused by many things, one of them is the lack of knowledge and awareness about the ICT governance, so there are still many government agencies which have not yet implemented properly the ICT governance. By using quantitative approaches, questionnaire instrument was adapted from the General Guide of the National ICT Governance. Framework COBIT and data analysis techniques adopted from the COBIT Maturity level. This study aims to explore the guidelines as an evaluation tool for the governance of the ICT system planning in Department of Communications and Information Technology in Bitung City. The results of this study found that the institution is still at low level, level 1 with 0,63 maturity level in governance planning of ICT system.
\end{abstract}

Keywords: ICT governance,planning system, evaluation.

\begin{abstract}
Abstrak
Intensitas penggunaan TIK di instansi pemerintah terus meningkat. Salah satu komponen proses TIK yang cukup penting adalah pengelolaan perencanaan sistem TIK, jika pengelolaan TIK baik maka perencanaan sistem TIK juga akan memberikan manfaat yang signifikan terhadap organisasi. Penelitian ini akan menlusuri dan mengukur sampai di mana dan bagaimana penerapan tata kelola perencanaan sistem TIK di Dinas Komunikasi dan Informatika Kota Bitung. Tujuannya adalah untuk mengetahui kondisi penerapan tata kelola TIK yang ada di Dinas Komunikasi dan Informatika Kota Bitung Dengan menggunakan pendekatan kuantitatif deskriptif, instrumen yang diadaptasi dari Panduan Umum Tata Kelola TIK Nasional dan Framework COBIT serta teknik analisis data yang diadopsi dari Cobit Maturity Model, penelitian ini mencoba mengeksplorasi panduan tersebut untuk kemudian digunakan sebagai tools evaluasi tata kelola perencanaan sistem TIK terhadap Dinas Kominfo Kota Bitung. Hasil dari penelitian ini menemukan bahwa Dinas Kominfo Kota Bitung dari sisi tata kelola perencanaan sistem TIK masih berada pada level rendah, yaitu level 1 dengan nilai tingkat kematangan sebesar 0.63.
\end{abstract}

Kata kunci: tata kelola TIK, perencanaan sistem, evaluasi. 


\section{PENDAHULUAN}

Keberhasilan sistem informasi selain diukur dengan melalui efisiensi dalam hal meminimalkan biaya, waktu, dan penggunaan sumber daya, juga harus diukur dengan efektivitas teknologi informasi dalam mendukung strategi organisasi (Simarmata, 2006). Hal tersebut membuat teknologi informasi dan komunikasi (TIK) menjadi bagian yang sangat penting. Peran TIK tidak hanya sekadar meningkatkan efektivitas serta efisiensi proses bisnis organisasi atau sebagai pendukung terbentuknya inovasi-inovasi, namun TIK juga merupakan pendukung dalam pengambilan keputusan yang keseluruhannya bertujuan untuk mendukung tujuan atau visi misi organisasi.

Sejalan dengan jiwa e-government yakni suatu usaha penciptaan suasanan penyelenggaraan pemerintah yang sesuai dengan objektif bersama (shared goals) dari sejumlah komunitas yang berkepentingan (Indrajid, 2005) tuntutan reformasi birokrasi untuk mewujudkan tata kelola pemerintahan yang baik (good governance) yang diamanatkan di Instruksi Presiden No.3 Tahun 2003 tentang Kebijakan dan Strategi Nasional Pengembangan E-government (Inpres, 2003) membuat setiap institusi pemerintah terus melakukan perbaikanperbaikan terhadap sistem yang telah ada. Perbaikan tersebut sebagian tertuang dalam bentuk kebijakan, salah satu contohnya adalah adanya Peraturan Pemerintah RI Nomor 82 Tahun 2012 tentang Penyelenggaraan Sistem dan Transaksi Elektronik. Peraturan tersebut membuat fungsi manajemen dalam organisasi menjadi sangat penting di mana manajemen adalah merupakan suatu tim yang disusun dalam organisasi untuk menjadi pengendali organisasi untuk mencapai tujuan-tujuan dan sasaran-sasaran yang hendak dicapai oleh organisasi (Nugroho, 2008).

Khusus menyangkut kebijakan tata kelola, pemerintah dalam hal ini Kementerian Komunikasi dan Informatika telah mengeluarkan Peraturan Menteri Kominfo No.41 Tahun 2007 tentang Panduan Umum
Tata Kelola TIK Nasional. Aturan ini berdasarkan peruntukkannya ditujukan bagi seluruh instansi pemerintah di semua level, yakni kementerian atau LPND di tingkat pusat, provinsi, dan kabupaten/kota.

Penerapan dan pemanfaatan TIK dalam sebuah organisasi harus didukung dengan tata kelola TIK yang baik, agar pemanfaatan TIK betul-betul efektif dan efisien dalam mencapai tujuan organisasi. Beberapa negara maju seperti Amerika Serikat, Australia, dan negara lainnya sudah memunyai dan menerapkan dengan baik standar tata kelola TIK yang dirancang untuk negaranya masingmasing.

Peraturan Menteri Kominfo No.41 Tahun 2007 tentang Panduan Umum Tata Kelola TIK Nasional yang dikeluarkan Kementerian Komunikasi dan Informatika merupakan standar tata kelola yang resmi yang bisa dijadikan acuan setiap instansi pemerintah dalam menata kelola TIK di lingkungannya masing-masing. Implementasi Peraturan Menteri Kominfo tersebut di masing-masing instansi pemerintah perlu dievaluasi, untuk mengetahui apakah peraturan menteri tersebut sudah cukup baik ataukah memerlukan revisi atau perubahan. Selain itu, masing-masing instansi pemerintah bisa melakukan evaluasi tata kelola TIK berdasarkan peraturan menteri tersebut untuk mengukur serta meningkatkan kinerja instansinya.

Pemerintah Kota Bitung, dalam hal ini Dinas Kominfo Kota Bitung, merupakan instansi yang diberi kepercayaan untuk melaksanakan urusan pemerintahan daerah di bidang komunikasi dan informatika. Salah satu tugas fungsinya adalah penyelenggaraan dan pengembangan sistem informasi dan telematika. Saat ini, Dinas Kominfo Kota Bitung memiliki tugas yang cukup berat karena selain penyelenggaraan dan pengembangan sistem informasi di masyarakat, Dinas Kominfo Kota Bitung juga bertanggungjawab terhadap Satuan Kerja Perangkat Daerah (SKPD) lainnya yang ada di Kota Bitung.

Kota Bitung merupakan kota dengan banyak potensi alami yang saat ini sedang 
dieksplorasi dengan pesat. Dari segi geografis, Kota Bitung merupakan pintu gerbang perdagangan, transportasi, dan pariwisata di kawasan Asia Pasifik. Oleh karena itu, Pelabuhan Kota Bitung belum lama ini dicanangkan sebagai Pelabuhan Hubungan Internasional dan juga ditetapkan sebagai Kawasan Ekonomi Khusus (KEK). Pencapaian Kota Bitung dalam mewujudkan apa yang telah dicanangkan dan ditetapkan tersebut, selain membutuhkan dukungan dari banyak pihak, juga membutuhkan dukungan TIK yang bagus. TIK yang bagus membutuhkan penerapan tata kelola TIK yang baik pula. Penerapan TIK di instansiinstansi pemerintah apabila dilakukan dengan tanpa pengawasan dan pengelolaan yang baik maka akan berpotensi terjadinya pemborosan anggaran dan terhambatnya pencapaian tujuan. Tata kelola TIK yang dilakukan secara tidak efektif akan memicu adanya investasi TIK yang tidak diharapakan seperti: efisiensi dan proses inti perusahaan terpengaruh secara negatif oleh rendahnya kualitas penggunaan TIK, kegagalan dari inisiatif TIK untuk melahirkan inovasi, serta biaya lebih tinggi dari yang diperkirakan dan kualitas yang lebih rendah dari yang telah diantisipasi (Astuti, 2008)

Dalam penelitian ini akan ditelusuri dan diukur sampai di mana dan bagaimana penerapan tata kelola perencanaan sistem TIK di Dinas Komunikasi dan Informatika Kota Bitung. Tujuan dari penelitian ini adalah untuk mengetahui kondisi penerapan tata kelola TIK yang ada di Dinas Komunikasi dan Informatika Kota Bitung serta memberikan masukan atau rekomendasi perbaikan terhadap penatakelolaan tersebut. Adapun manfaat penelitian ini ialah sebagai bahan pembanding dan rujukan bagi organisasi yang menerapkan tata kelola pada proses perencanaan sistem TIK.

\section{LANDASAN KONSEP}

\section{Penelitian Terdahulu}

Penelitian sejenis yang telah dilakukan, beberapa di antaranya adalah yang dilakukan oleh Alvin, dkk "Analisis dan Evaluasi Tata Kelola IT pada PT.FIF", penelitian ini menggunakan best practice COBIT 5 sebagai panduan dalam melaksanakan proses evaluasi, adapun hasil evaluasi terhadap objek penelitian yang merupakan organisasi waralaba adalah sebesar 2,38, salah satu temuaannya adalah tidak adanya standar operasional prosedur terhadap beberapa proses seperti Ensure Resource Optimization, Manage the Management Framwork for IT, Manage Budget and Costs, Manage Human Resources, Manage Quality, Manage Organizational Change Enablement, Manage Programme and Projects, Manage Knowledge, Monitor, Evaluate, and Assess Performance and Conformance, Monitor, Evaluate and Assess the System of Internal Control. Hardika Kristia Williasta "Analisis Tata Kelola TI di Kabupaten Semarang", penelitian ini menggunakan best practice COBIT 4, dengan hasil evaluasi terhadap obyek organisasi yang mirip dengan penelitian ini yaitu instansi pemerintah, sebesar 3.14, temuan dari penelitian ini yaitu performa buruk terhadap domain plan and Organise (PO) 1, PO 2 dan $P O \quad 7$ yang terdapat pada panduan COBIT 4 yang digunakan dalam mengevaluasi. Perbedaan kedua penelitian tersebut terhadap penelitian ini adalah pada penggunaan panduan yang digunakan dalam melakukan evaluasi, penelitian ini menggunakan panduan umum tata kelola TIK nasional.

\section{Panduan Umum Tata Kelola Teknologi Informasi dan Komunikasi (TIK) Nasional}

Panduan Umum Tata Kelola Teknologi Informasi dan Komunikasi Nasional, versi 1 2007 merupakan bagian dari Peraturan Menteri Komunikasi dan Informatika Nomor: 41/PER/MEN.KOMINFO/11/2007 tentang Panduan Umum Tata Kelola Teknologi Informasi dan Komunikasi Nasional. Model tata kelola TIK nasional difokuskan pada pengelolaan proses-proses TIK melalui mekanisme pengarahan, monitoring, serta evaluasi. Model keseluruhan tata kelola TIK nasional adalah sebagai berikut: 
Penetapan entitas struktur tata kelola dimaksudkan untuk memastikan kapasitas kepemimpinan yang memadai dan hubungan antarsatuan kerja/institusi pemerintahan yang sinergis dalam perencanaan, penganggaran, realisasi sistem TIK, operasi sistem TIK, dan evaluasi secara umum implementasi TIK di pemerintahan. Adapun ketentuan umum terkait dengan struktur tata kelola adalah pembentukan CIO dan Komite TIK di tiap institusi pemerintahan merupakan prioritas, di samping entitas-entitas struktur tata kelola TIK yang sudah ada sebelumnya.

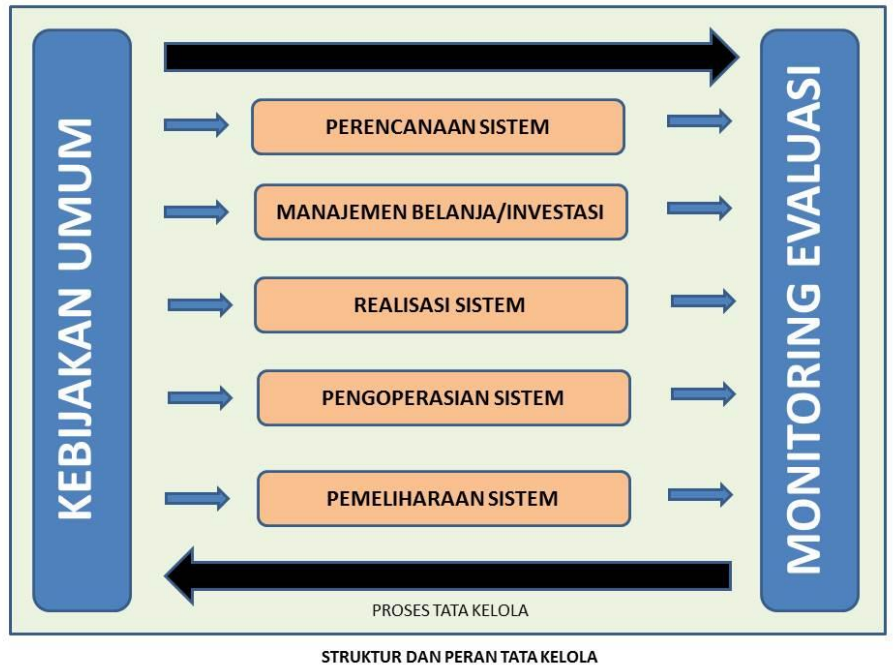

Sumber: Peraturan Menteri Kominfo No.41 Tahun 2007 Tentang panduan Umum Tata Kelola TIK Nasional.

\section{Gambar 1 Model Tata Kelola TIK Nasional}

Eksekutif Institusi Pemerintahan, yaitu pimpinan institusi pemerintahan (Kabupaten/kota, Provinsi, Kementerian, Lembaga Pemerintah Non Kementerian), Satuan Kerja Pengelola TIK, yaitu satuan kerja yang bertugas dalam pengelolaan TIK institusi pemerintahan. Posisi struktural satuan kerja pengelola TIK ini saat ini memunyai level struktural yang berbeda-beda di institusi-institusi pemerintahan, satuan pemilik proses bisnis, yaitu satuan kerja di luar satuan kerja pengelola TIK sebagai pemilik proses bisnis (business process owner).

\section{Proses Tata Kelola Perencanaan Sistem}

Proses tata kelola perencanaan sistem ditujukan untuk memastikan bahwa tujuantujuan utama tata kelola dapat tercapai, terkait dengan pencapaian tujuan organisasi, pengelolaan sumber daya, dan manajemen risiko. Perencanaan sistem merupakan proses yang ditujukan untuk menetapkan visi, arsitektur TIK dalam hubungannya dengan kebutuhan organisasi dan rencana realisasi atas implementasi visi dan arsitektur TIK tersebut. Rencana TIK yang telah disusun akan menjadi referensi bersama bagi seluruh satuan kerja dalam sebuah institusi atau referensi bersama beberapa institusi yang ingin menyinergiskan inisiatif TIKnya. Adapun siklus dan lingkup perencanaan sistem adalah sebagai berikut: (a) Setiap institusi pemerintahan memiliki rencana induk TIK lima tahunan yang akan menjadi dasar dalam pelaksanaan inisiatif TIK tahunan, dengan memerhatikan keselarasan dengan rencana flagship TIK Nasional; (b) Setiap institusi pemerintahan minimal harus memiliki perencanaan atas komponen berikut ini: Perencanaan Arsitektur Informasi, Perencanaan Arsitektur Aplikasi, Perencanaan Arsitektur Infrastruktur Teknologi, Perencanaan Manajemen dan Organisasi serta Pendekatan dan Roadmap Implementasi. Selain dari kedua hal tersebut, diperlukan juga mekanisme pengendalian 
serta evaluasi sistem secara berkala untuk menjamin sistem yang berjalan sudah sesuai dengan visi dan misi organisasi. Hal yang harus diperhatikan dalam mekanisme pengendalian adalah hal-hal seperti apa yang harus dikerjakan, siapa yang melakukannya dan kapan akan dilaksanakan (Sutarbi, 2005).

Beberapa faktor yang diidentifikasi dapat menjadi penghambat dalam penerapan tata kelola TIK adalah (Marcel, 2012) :

1. Lemahnya kepemimpinan di bidang TI, kurangnya inovasi atau ketidakmampuan untuk mewujudkan inovasi dalam bentuk inisiatif TI menjadi realita;

2. Ketidakmampuan unit yang menangani pengadaan proyek TI karena kurangnya pengetahuan di sisi teknis;

3. Masih belum adanya proses yang formal dalam menentukan prioritas investasi TI;

4. Khusus untuk instansi pemerintah, perubahan seperti pemotongan anggaran dapat berpengaruh pada penentuan prioritas investasi TI;

5. Justifikasi dari investasi TI terlalu berfokus pada faktor-faktor finansial tradisional;

6. Ada tarik-menarik kepentingan di antara unit-unit karena masalah kepemilikan data;

7. Setiap unit bisnis cenderung memiliki inisiatif/proyek TI masing-masing, menghasilkan duplikasi data, sistem yang kompleks, dan saling tumpang tindih;

8. Adanya unit-unit bisnis yang melakukan pengadaan TI tanpa sepengetahuan unit TI, sehingga menyulitkan dalam pendataan aset, yang berdampak pada kualitas layanan TI terkait perawatan dan perbaikan;

9. Khusus untuk instansi pemerintah, adanya aturan yang mensyaratkan bahwa proyek harus diselesaikan dalam kurun waktu 1 tahun, sedangkan ada proyek-proyek TI yang sifatnya tahunan (multiyears), melibatkan hubungan jangka panjang;

\section{Cobit Maturity Model}

Salah satu alat pengukuran dari kinerja suatu sistem teknologi informasi adalah model kematangan (maturity model) (ITGI, 2007). Model kematangan untuk pengelolaan dan pengendalian pada proses teknologi informasi didasarkan pada metode evaluasi organisasi sehingga dapat mengevaluasi sendiri dari level 0 (tidak ada) hingga level 5 (Optimis). Model kematangan dimaksudkan untuk mengetahui keberadaan persoalan yang ada dan bagaimana menentukan prioritas peningkatan. Model kematangan dirancang sebagai profil proses teknologi informasi, sehingga organisasi akan dapat mengenali sebagai deskripsi kemungkinan keadaan sekarang dan mendatang. Penggunaan model kematangan yang dikembangkan untuk setiap 34 proses teknologi informasi memungkinkan manajemen dapat mengidentifikasi: (a) Kondisi perusahaan sekarang; (b) Kondisi sekarang dari industri untuk perbandingan; (c) Kondisi yang diinginkan perusahaan; (d) Pertumbuhan yang diinginkan antara as-is dan to-be (ITGI, 2007).

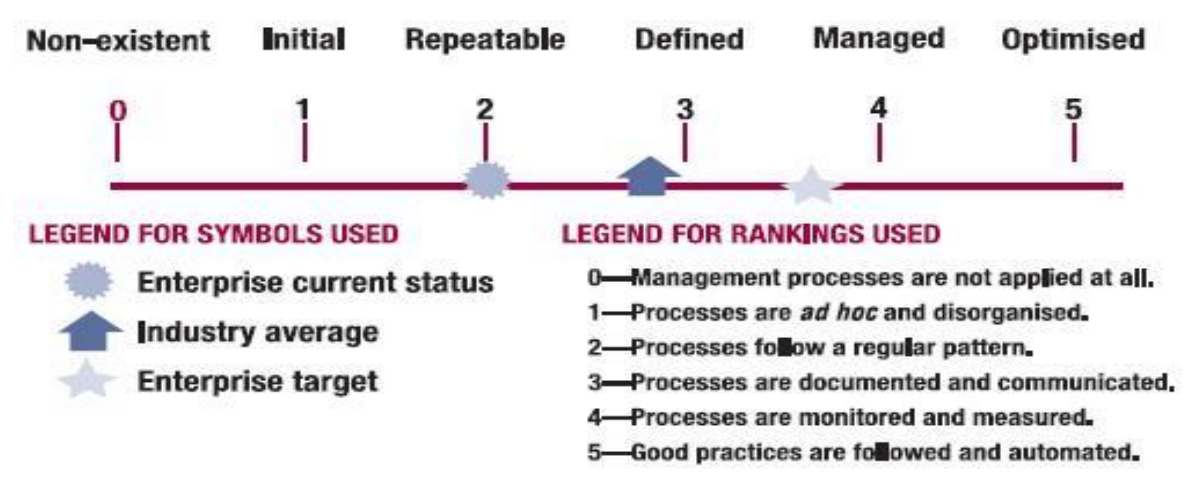

Sumber: ITGI, 2007

Gambar 2

Urutan Tingkat Kematangan 
Tabel 1

Level Kematangan Tata Kelola Teknologi Informasi pada Perusahaan

\begin{tabular}{cc}
\hline Indeks kematangan & Level kematangan \\
\hline $0-0.49$ & $0-$ Non-Existent \\
$0.50-1.49$ & $1-$ Initial/Ad Hoc \\
$1.50-2.49$ & $2-$ Repeatable But Intutitive \\
$2.50-3.49$ & $3-$ Defined Process \\
$3.50-4.49$ & $4-$ Managed and Measureabel \\
$4.50-5.00$ & $5-$ Optimized \\
\hline
\end{tabular}

Sumber: ITGI, 2007.

Gambar 2 menggambarkan urutan tingkat kematangan tata kelola teknologi informasi dalam perusahaan. Jika dikelompokkan berdasarkan nilai level kematangan, maka dapat dirinci seperti pada tabel 1 .

Keterangan masing-masing level kematangan pada tabel 1 di atas adalah sebagai berikut:

- Non-eksistent $(0=$ Management processes are not applied at all). Kekurangan yang menyeluruh terhadap proses apa pun yang dapat dikenali. Perusahaan bahkan tidak mengetahui bahwa terdapat permasalahan yang harus diatasi.

- Adhoc (1= Processes are ad hoc and disorganized). Terdapat bukti bahwa perusahaan mengetahui adanya permasalahan yang harus diatasi. Bagaimanapun juga tidak terdapat proses standar, namun menggunakan pendekatan ad hoc yang cenderung diperlakukan secara individu atau per kasus. Secara umum pendekatan kepada pengelolaan proses tidak terorganisasi.

- Repeatable $(2=$ Processes/allow a regular pattern). Proses dikembangkan ke dalam tahapan di mana prosedur serupa diikuti pihak-pihak yang berbeda untuk pekerjaan yang sama. Tidak terdapat pelatihan formal atau pengomunikasian prosedur standar dan tanggung jawab diserahkan kepada individu masing-masing. Terdapat tingkat kepercayaan yang tinggi terhadap pengetahuan individu sehingga kemungkinan terjadi error sangat besar.

- Defined (3= Processes are documented and communicated). Prosedur distandarisasi dan didokumentasikan, kemudian dikomunikasikan melalui pelatihan. Selanjutnya, diamanatkan bahwa proses-proses tersebut harus diikuti. Namun, penyimpangan tidak mungkin dapat terdeteksi. Prosedur sendiri tidak lengkap, namun sudah memformalkan praktik yang berjalan.

- Managed (4= Processes are monitored and measured). Manajemen mengawasi dan mengukur kepatutan terhadap prosedur dan mengambil tindakan jika proses tidak dapat dikerjakan secara efektif. Proses berada di bawah peningkatan yang konstan dan penyediaan praktik yang baik. Otomatisasi dan perangkat digunakan dalam batasan tertentu.

- Optimized (5= Best practices are followed and automated). Proses telah dipilih ke dalam tingkat praktik yang baik, berdasarkan hasil dari perbaikan berkelanjutan dan pemodelan kedewasaan dengan perusahaan lain. Teknologi informasi digunakan sebagi cara terintegrasi untuk mengotomatisasi alur kerja, penyediaan alat untuk peningkatan kualitas dan efektivitas serta membuat perusahaan cepat beradaptasi.

\section{METODE PENELITIAN}

Penelitian ini merupakan penelitian deskriptif. Lokasi penelitian dilakukan di salah satu instansi pemerintah di Kota Bitung Provinsi Sulawesi Utara yaitu Dinas Kominfo Kota Bitung. Pendekatan yang digunakan dalam penelitian ini bersifat evaluatif. Secara umum, terdapat dua jenis penelitian evaluasi, yakni evaluasi formatif dan evaluasi 
summatif. Evaluasi formatif biasanya melihat dan meneliti pelaksanaan suatu program, mencari umpan balik untuk memperbaiki pelaksanaan program tersebut. Evaluasi summatif biasanya dilaksanakan pada akhir program untuk mengukur ketercapaian program. Berdasarkan hal tersebut maka penelitian ini termasuk penelitian evaluasi formatif.

Metode penelitian yang digunakan adalah pendekatan gabungan kuantitatif dan kualitatif, mengutip pendapat Gray dalam Tukiran (2012), bahwa kedua metode tersebut dapat digunakan secara bersama, bargantian maupun digabung seperti skema pada gambar 3.
Berdasarkan Gambar 3 di atas, maka penelitian ini menggunakan skema model nomor 3. Tahap awal dari penelitian ini adalah melakukan studi literatur dan pembuatan instrumen penelitian, kemudian tahapan selanjutnya melakukan pengumpulan data. Pengumpulan data dilakukan dengan teknik wawancara terstruktur, wawancara terstruktur digunakan sebagai teknik pengumpulan data, bila peneliti atau pengumpul data telah mengetahui dengan pasti tentang informasi apa yang akan diperoleh (Sugiyono, 2013). Oleh karena itu

\begin{tabular}{|c|c|c|c|}
\hline $\begin{array}{l}\text { 1. KUALITATIF } \\
\text { Eksplorasi }\end{array}$ & $\begin{array}{l}\text { KUANTITATIF } \\
\text { Kuesioner }\end{array}$ & $\longrightarrow$ & $\begin{array}{c}\text { KUALITATIF } \\
\text { Mendalami dan Mengakses } \\
\text { hasil }\end{array}$ \\
\hline $\begin{array}{l}\text { 2. KUANTITATIF } \\
\text { Survei }\end{array}$ & $\begin{array}{l}\text { KUALITATIF } \\
\text { Kuesioner }\end{array}$ & & $\begin{array}{l}\text { KUANTITATIF } \\
\text { Eksperimen }\end{array}$ \\
\hline 3. KUALITATIF & $\begin{array}{c}\text { Meneruskan } \\
\text { pengumpulan data } \\
\text { ringkas }\end{array}$ & $\longrightarrow$ & KUANTITATIF \\
\hline
\end{tabular}

4. KUANTITATIF

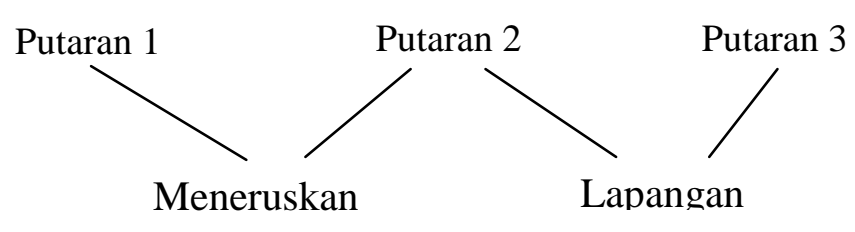

KUALITATIF

Sumber: Gray, 2009.

\section{Gambar 3}

Empat Model Metode Gabungan

penelitian ini menggunakan teknik wawancara terstruktur. Data informan terlihat pada tabel 2. Selain wawancara, dilakukan juga pengamatan langsung terhadap komponen-komponen yang terkait dalam tata kelola TIK, salah satu contohnya adalah pengamatan terhadap sistem aplikasi-aplikasi TIK yang telah berjalan saat ini.
Tahap setelah pengumpulan data adalah tahap analisis data, pada tahap ini terlebih dahulu dilakukan perhitungan atau skoring terhadap data-data yang telah didapatkan dari tahapan pengumpulan data. Perhitungan dilakukan dengan mengadopsi teknik perhitungan yang digunakan oleh framework tata kelola COBIT 4. 
Tabel 2

Nara sumber penelitian

\begin{tabular}{|c|c|c|}
\hline RACI Respondent & Actual Respondent & Jabatan \\
\hline Chief Executive Officer & Chief Executive Officer & Kepala Bagian PDE \\
\hline Chief Information Officer & IT Director & $\begin{array}{l}\text { Kepala Sub Bagian SI dan } \\
\text { Perangkat Lunak }\end{array}$ \\
\hline Business Process Owner & $\begin{array}{l}\text { Human Resource Director, Human } \\
\text { Resource Head Division, Human Resource } \\
\text { Manager, System Analyst Manager }\end{array}$ & $\begin{array}{l}\text { KABAG PDE, KASUBAG SI } \\
\text { dan Perangkat Lunak, } \\
\text { KASUBAG Infrastruktur } \\
\text { jaringan }\end{array}$ \\
\hline Head Operation & IT Head Division & $\begin{array}{l}\text { KABAG PDE, KASUBAG SI } \\
\text { dan Perangkat Lunak, } \\
\text { KASUBAG Infrastruktur } \\
\text { jaringan }\end{array}$ \\
\hline Chief Architect & IT Hardware Manager, IT Aset Manager & KASUBAG \\
\hline Head IT Administration & IT Administration Manager & Administrasi \\
\hline $\begin{array}{l}\text { Compliance, Audit, Risk and } \\
\text { Security }\end{array}$ & Internal Auditor & KABAG dan KASUBAG \\
\hline Service Desk Manager & IT Trouble Shooting Manager & Bagian Teknisi \\
\hline
\end{tabular}

Sumber: Hardika Kristia Williasta (2012).

\section{HASIL PENELITIAN DAN PEMBAHASAN}

Kebijakan tata kelola teknologi informasi dan komunikasi (TIK) di Indonesia yang berlaku saat ini merujuk pada Peraturan Menteri Komunikasi dan Informatika Nomor 41 tahun 2007 tentang Panduan Umum Tata Kelola Teknologi Informasi Dan Komunikasi Nasional. Tujuan tata kelola TIK adalah memberikan batasan dan panduan bagi institusi pemerintahan dan entitas pengambil keputusan dalam pengelolaan sumber daya TIK. Adapun beberapa manfaatnya adalah mengoptimalkan ketercapaian value dari penyelenggaraan TIK di lingkungan kerjanya masing-masing: internal manajemen dan pelayanan publik serta memudahkan monitoring dan evaluasi TIK di seluruh instansi Pemerintah.

\section{Pengukuran Tata Kelola Perencanaan Sistem TIK}

Pengukuran tata kelola perencanaan sistem TIK pada penelitian ini menggunakan control objektives yang bersumber dari panduan umum tata kelola TIK Nasional yang tertuang dalam Peraturan Menteri
Komunikasi dan Informatika Nomor: 41/PER/MEN.KOMINFO/11/2007 dan juga Framework Cobit 4. Proses-proses tata kelola perencanaan sistem TIK ditujukan untuk memastikan bahwa tujuan-tujuan utama tata kelola dapat tercapai, terkait dengan pencapaian tujuan organisasi, pengelolaan sumber daya, dan manajemen risiko. Pengukuran tata kelola perencanaan sistem TIK terdiri dari beberapa level yang dimulai dari level 0 sebagai level terendah sampai dengan level 5 sebagai level tertinggi. Secara umum, pengukuran ini adalah untuk menggambarkan sampai di mana tingkat kesadaran akan pentingnya peran arsitektur informasi, bagaimana proses perencanaan arsitektur informasi yang berjalan saat ini serta juga bagaimana pengembangannya.

Berikut adalah hasil pengukuran proses tata kelola perencanaan sistem TIK: Pengukuran proses perencanaan Arsitektur Informasi (AI).

Hasil pengukuran proses perencanaan arsitektur informasi pada Dinas Kominfo Kota Bitung adalah 0.73. Nilai ini masuk pada level 1 atau initial/ad hoc pada ketentuan nilai kematangan tata kelola teknologi informasi. Dari nilai yang dihasilkan dapat ditarik kesimpulan bahwa pengelolaan perencanaan arsitektur informasi 
Tabel 3

Pengukuran Proses Perencanaan Arsitektur Informasi

\begin{tabular}{cccc}
\hline Level Kematangan & Tingkat Kepatutan & $\begin{array}{c}\text { Kontribusi Tiap } \\
\text { Level }\end{array}$ & Nilai \\
\hline 0 & 0.11 & 0.00 & 0.00 \\
1 & 0.26 & 0.30 & 0.08 \\
2 & 0.22 & 0.70 & 0.15 \\
3 & 0.06 & 1.00 & 0.06 \\
4 & 0.17 & 1.30 & 0.21 \\
5 & 0.13 & 1.70 & 0.22 \\
& Tingkat kematangan proses TI & & 0.73 \\
\hline
\end{tabular}

Sumber: data hasil perhitungan kuesioner/angket penelitian.

masih dilakukan secara ad hoc atau dengan kata lain arsitektur informasi akan dikerjakan jika ada permintaan kebutuhan akan hal tersebut, tidak ada evaluasi secara berkala, tidak ada pengembangan, serta tidak menggunakan standar tata kelola TIK.

Hasil pengukuran proses perencanaan arsitektur aplikasi pada Dinas Kominfo Kota Bitung adalah 0.38. Nilai ini masuk pada level 0 atau Non-Existent pada ketentuan nilai kematangan tata kelola teknologi informasi. Dari nilai yang dihasilkan dapat ditarik kesimpulan bahwa proses pengelolaan perencanaan arsitektur aplikasi tidak dilakukan dengan baik, penggunaan aplikasiaplikasi yang digunakan untuk operasionalisasi tidak terdokumentasi dengan baik.

Hasil pengukuran proses perencanaan arsitektur infrastruktur teknologi pada Dinas Kominfo Kota Bitung adalah 0.33. Nilai ini masuk pada level 0 atau Non-Existent pada ketentuan nilai kematangan tata kelola teknologi informasi. Kondisi ini juga sama dengan pengelolaan arsitektur aplikasi, kesadaran terhadap pentingnya penataan terhadap infrastruktur teknologi masih rendah.

Tabel 4

Pengukuran Proses Perencanaan Arsitektur Aplikasi

\begin{tabular}{cccc}
\hline Level Kematangan & Tingkat Kepatutan & $\begin{array}{c}\text { Kontribusi Tiap } \\
\text { Level }\end{array}$ & Nilai \\
\hline 0 & 0.00 & 0.00 & 0.00 \\
1 & 0.04 & 0.30 & 0.04 \\
2 & 0.08 & 0.70 & 0.08 \\
3 & 0.11 & 1.00 & 0.11 \\
4 & 0.04 & 1.30 & 0.04 \\
5 & 0.11 & 1.70 & 0.11 \\
& Tingkat kematangan proses TI & & 0.38 \\
\hline
\end{tabular}

Sumber: data hasil perhitungan kuisioner/angket penelitian.

Tabel 5

Pengukuran Proses Perencanaan Arsitektur Infrastruktur Teknologi

\begin{tabular}{cccc}
\hline Level Kematangan & Tingkat Kepatutan & $\begin{array}{c}\text { Kontribusi Tiap } \\
\text { Level }\end{array}$ & Nilai \\
\hline 0 & 0.00 & 0.00 & 0.00 \\
1 & 0.04 & 0.30 & 0.06 \\
2 & 0.08 & 0.70 & 0.08 \\
3 & 0.11 & 1.00 & 0.06 \\
4 & 0.04 & 1.30 & 0.04 \\
5 & 0.11 & 1.70 & 0.09 \\
& Tingkat kematangan proses TI & 0.33 \\
\hline
\end{tabular}

Sumber: data hasil perhitungan kuisioner/angket penelitian. 
Tabel 6

Pengukuran Proses Perencanaan Manajemen dan Organisasi

\begin{tabular}{cccc}
\hline Level Kematangan & Tingkat Kepatutan & $\begin{array}{c}\text { Kontribusi Tiap } \\
\text { Level }\end{array}$ & Nilai \\
\hline 0 & 0.50 & 0.00 & 0.00 \\
1 & 0.44 & 0.30 & 0.13 \\
2 & 0.66 & 0.70 & 0.46 \\
3 & 0.39 & 1.00 & 0.39 \\
4 & 0.17 & 1.30 & 0.21 \\
5 & 0.00 & 1.70 & 0.00 \\
& Tingkat kematangan proses TI & & 1.20 \\
\hline
\end{tabular}

Sumber: data hasil perhitungan kuisioner/angket penelitian.

Hasil pengukuran proses perencanaan manajemen dan organisasi pada Dinas Kominfo Kota Bitung adalah 1.2. Nilai ini masuk pada level 1 atau ad hoc pada ketentuan nilai kematangan tata kelola teknologi informasi.

Hasil pengukuran proses perencanaan pendekatan dan roadmap implementasi pada Dinas Kominfo Kota Bitung adalah 0.51. Nilai ini masuk pada level 1 atau ad hoc pada ketentuan nilai kematangan tata kelola teknologi informasi.

Setelah mengukur dari kelima proses perencanaan di atas, maka dapat diketahui nilai tingkat kematangan tata kelola perencanaan sistem TIK sebagaimana tergambar pada Tabel 7.

Berdasarkan hasil pengukuran tingkat kematangan pada tabel di atas serta hasil wawancara mendalam terkait capaian level yang diharapkan, maka dapat diketahui nilai kesenjangan yang terjadi saat ini. Berikut adalah tabel nilai kesenjangan tersebut:

Dari tabel di atas, terlihat nilai gap/kesenjangan saat ini dengan nilai yang diharapkan yakni sebesar $2.37 \%$. Nilai gap tersebut cukup besar, dibutuhkan waktu serta kerja keras untuk mencapai nilai yang diharapkan. Nilai yang diharapakan didapatkan dari hasil proses wawancara yang telah dilakukan pada tahap pengambilan data.

Tabel 7

Pengukuran Proses Perencanaan Pendekatan Roadmap Implementasi

\begin{tabular}{cccc}
\hline Level Kematangan & Tingkat Kepatutan & $\begin{array}{c}\text { Kontribusi Tiap } \\
\text { Level }\end{array}$ & Nilai \\
\hline 0 & 0.00 & 0.00 & 0.00 \\
1 & 0.00 & 0.30 & 0.00 \\
2 & 0.11 & 0.70 & 0.08 \\
3 & 0.00 & 1.00 & 0.00 \\
4 & 0.33 & 1.30 & 0.43 \\
5 & 0.00 & 1.70 & 0.00 \\
& Tingkat kematangan proses TI & & 0.51 \\
\hline
\end{tabular}

Sumber: data hasil perhitungan kuisioner/angket penelitian.

Tabel 8

Tingkat Kematangan Tata Kelola Perencanaan Sistem TIK

\begin{tabular}{lcc}
\multicolumn{1}{c}{ Control objective } & Nilai & Kondisi \\
\hline Arsitektur Informasi (AI) & 0.73 & Initial/adhoc \\
Arsitektur Aplikasi (AA) & 0.38 & Non-existent \\
Arsitektur Infrastruktur Teknologi (AIT) & 0.33 & Non-existent \\
Manajemen dan Organisasi (MO) & 1.20 & Initial/adhoc \\
Pendekatan dan Roadmap Implementasi (PRI) & 0.51 & Initial/adhoc \\
\multicolumn{1}{c}{ Rata-rata } & 0.63 & Initial/adhoc \\
\hline
\end{tabular}

Sumber: data hasil perhitungan kuisioner/angket penelitian. 
Tabel 9

Kesenjangan Tingkat Kematangan Saat Ini

\begin{tabular}{cccc}
\hline Control objective(Domain) & Nilai saat ini & Diharapkan & Gap/Kesenjangan \\
\hline AI & 0.73 & 3 & $3-0.73=2.27$ \\
AA & 0.38 & 3 & $3-0.38=2.62$ \\
AIT & 0.33 & 3 & $3-0.33=2.67$ \\
MO & 1.20 & 3 & $3-1.20=1.8$ \\
PRI & 0.51 & 3 & $3-0.51=2.49$ \\
& \multicolumn{2}{c}{ Rata-rata } & 2.37 \\
\hline
\end{tabular}

Sumber: data hasil perhitungan kuisioner/angket penelitian.

Adapun beberapa temuan yang didapatkan dalam penelitian ini berdasarkan komponen arsitektur informasi adalah ditemukan bahwa alur proses informasi tidak ada, keluar masuknya informasi serta penggunaannya tidak memiliki prosedur. Meskipun ada keinginan untuk membuat arsitektur informasi, namun banyak kendala untuk mewujudkannya, salah satunya adalah sulitnya berkoordinasi dengan Satuan Kerja Perangkat Daerah (SKPD) lainnya untuk berdiskusi mengenai pembentukan arsitektur informasi. Dukungan SDM kurang memadai. Temuan terhadap komponen arsitektur aplikasi adalah belum ada draft ataupun konsep arsitektur aplikasi, belum ada inisiatif untuk merancang arsitektur aplikasi. Dukungan SDM kurang memadai. Untuk komponen arsitektur infrastruktur teknologi ditemukan mengenai belum jelasnya pembagian tugas dan tanggung jawab untuk instalasi, pengembangan serta pemeliharaan infrastruktur teknologi di lingkungan Pemerintah Kota Bitung. Kurangnya SDM yang ahli bidang tekhnologi serta tidak adanya standar bentuk kerja sama dengan perusahaan lain di bidang teknologi untuk pengembangan infrastruktur teknologi di dalam organisasi. Dukungan SDM kurang memadai. Untuk komponen manajemen dan organisasi ditemukan bahwa tidak ada aturan atau kebijakan mengenai pengelolaan dan pemeliharaan sistem, dari struktur organisasi yang ada, tidak ada bagian yang secara khusus menangani manajeman sistem, dukungan SDM kurang memadai. Terakhir adalah temuan terhadap komponen pendekatan dan roadmap implementasi, ditemukan bahwa pelaksanaan pekerjaan tidak menggunakan konsep manajemen proyek di setiap proyek IT, tidak ada roadmap implementasi, tidak ada pelatihan manajemen proyek untuk staf, tidak ada dukungan SDM serta anggaran.

\section{PENUTUP}

\section{Simpulan}

Dinas Kominfo Kota Bitung belum menerapkan tata kelola teknologi informasi dengan baik. Dinas Kominfo Kota Bitung membutuhkan banyak perbaikan untuk meningkatkan kualitas tata kelola teknologi informasi yang baik.

Terdapat kelemahan pada semua domain tata kelola TIK yang ada pada panduan umum tata kelola TIK Nasional.

Panduan tata kelola TIK Nasional belum selaras dengan kebijakan yang ada mengenai struktur organisasi, panduan tata kelola menghendaki adanya struktur tersendiri khusus untuk penanganan tata kelola TIK sementara kebijakan diorganisasi belum memfasilitasi struktur tersebut.

\section{Saran}

Sebaiknya Dinas Kominfo Kota Bitung membentuk tim khusus yang akan menangani tata kelola TIK di Kota Bitung serta memberikan pelatihan yang sesuai terhadap tim tersebut, melakukan koordinasi kesemua SKPD yang ada untuk bersama-sama membuat arsitektur infrastruktur teknologi yang baik sejak dini, mulai membuat SOP terhadap pengelolaan dan pengembangan sistem dan memastikan SOP tersebut dijalankan dengan baik oleh seluruh staf, 
mulai memikirkan kemungkinan melakukan kerjasama dengan konsultan IT yang profesional untuk pengembangan sistem TIK di Kota Bitung.

Berkaitan dengan proses perencanaan sistem, rekomendasi terhadap komponen arsitektur informasi adalah alur proses informasi serta penggunaan alat teknis pendukungnya perlu distandardisasi dan didokumentasikan, kemudian disosialisasikan terhadap pengguna informasi.

\section{DAFTAR PUSTAKA}

\section{Buku:}

ITGI. (2007). COBIT 4.1 FrameworkControl Objectives-Management Guidelines-Maturity Models. In I. G. Institute. USA.

Jogiyanto, W. A. (2011). Sistem Tata Kelola Teknologi Informasi. Yogyakarta: Andi Yogyakarta.

Nugroho, E. (2008). Sistem Informasi Manajemen, Konsep, Aplikasi, dan Perkembangannya. Yogyakarta: Andi Yogyakarta.

Indrajit, Richardus Eko, D. R. (2005). eGovernment in action. Yogyakarta: Andi Yogyakarta.

Sugiyono, P. D. (2013). Metode Penelitian Kuantitatif Kualitatif dan $R \& D$. Bandung: Alfabeta.

Simarmata, J. (2006). Teknologi Komputer dan Informasi. Yogyakarta: Andi Yogyakarta.

Tukiran, S. E. (2012). Metode Penelitian Survei. Jakarta: LP3ES, anggota Ikapi.

Sutabri, Tata, S. M. (2005). Sistem Informasi Manajemen. Yogyakarta: Andi Yogyakarta.

\section{Jurnal:}

Astuti, R. (2008). Model Tata Kelola Teknologi Informasi Menggunakan Framework Cobit Pada Proses Pendidikan dan Pelatihan Pengguna. $e$ Indonesia Initiative 2008 (eII2008).
Jakarta: e-Indonesia Initiative 2008 (eII2008).

Marcel. (2012). Tata Kelola Teknologi Informasi Untuk Menggali Manfaat Strategis Teknologi Informasi Bagi Bisnis. Jurnal Teknik dan Ilmu Komputer, Vol. 1 No. 4 OktoberDesember 2012 hal. 438-449.

\section{Skirpsi / Tesis / Disertasi:}

Purnama, F. J. (2009). Penyusunan Tata Kelola Teknologi Informasi Untuk Pemerintah Kabupaten Bengkalis. Bandung: JBPTITBPP.

Williasta, Hardika Kristia. (2012). Analisis Tata Kelola TI di Kabupaten Semarang Menggunakan Cobit 4.1 Domain Plan and Organize Studi Kasus Bagian PDE Kabupaten Semarang. Skripsi, Universitas Kristen Satya Wacana.

\section{Institusi, Perusahaan, Atau Organisasi sebagai penulis:}

Kemkominfo. (2007). Panduan Umum Tata Kelola Teknologi Informasi dan komunikasi Nasional. Jakarta: Kementerian Komunikasi dan Informatika Republik Indonesia.

Peraturan Pemerintah. (2012). PP Nomor 82 Tahun 2012 Tentang Penyelenggaraan Sistem dan Transaksi Elektronik. Jakarta: Pemerintah Republik Indonesia.

Kemkominfo. (2007). Peraturan Menteri Nomor 41 Tahun 2007 Tentang Panduan Umum Tata Kelola TIK. Jakarta: Kementerian Komunikasi dan Informatika Republik Indonesia.

Inpres. (2003). Instruksi Presiden No.3 Tentang Kebijakan dan Strategi Nasional Pengembangan EGovernment. Jakarta. 